\title{
醬油醉造工程におけるステンレス鋼の耐食性*
}

\author{
島 貢**, 北村義治 $* *$ ，西沢有夫***，金子 智****，鈴木紹夫*****，渡辺勝也****** \\ ** 北海道工業大学経営工学科 \\ *** 福山醸造株式会社 \\ **** 日本金属工業株式会社研究開発本部 \\ ***** 味の素株式会社技術センター \\ $* * * * * *$ 北海道大学金属工学科
}

\section{Corrosion Resistance of the Stainless Steel in a Soy Sauce Brewing Process*}

\author{
Mitsugu Shima**, Yoshiharu Kitamura**, Ikuo Nishizawa***, \\ Satoru Kaneko****, Tsuguo Suzuki***** and Katsuya Watanabe****** \\ ** Department of Industrial Engineering, Hokkaido Institute of Technology \\ *** Fukuyama Brewing Co., Ltd. \\ **** Research and Development Headquarters, Nippon Metal Industry Co., Ltd. \\ ***** Technology and Engineering Center, Ajinomoto Co., Inc. \\ ****** Department of Metallurgical Engineering, Hokkaido University
}

Field corrosion tests of various kinds of stainless steel were carried out for ten years, partly for three years, to select optimum construction materials in the down stream of pasteurizing unit. Resistance to localized corrosion was also evaluated by measuring anodic polarization characteristics in soy sauce and sodium chloride solution. Pitting and crevice corrosion was the most remarkable with SUS 304, followed by SUS 316L and the least remarkable with SUS 317J1. Pitting and crevice corrosion of SUS 329J1 was less remarkable than these of SUS 444. The consistency of the result of field corrosion test for long term and the result of anodic polarization characteristics was confirmed. Dissolved oxygen concentrations and natural electrode potentials in soy sauce, amino acid, sodium chloride solution suggested that initiation and growth of the localized corrosion of stainless steels would be restrained in the brewing soy sauce, because of its lower concentration of dissolved oxygen than sodium chloride solution.

Key words: stainless steel, soy sauce brewing process, corrosion, pitting corrosion, crevice corrosion, sodium chloride, $\mathrm{NaCl}$, field corrosion test

\section{1. 緒言}

食品を製造, 加工する装置の構成材料は, 耐食性, 製 造工程への阻害のみならず, 食品衛生性の確保, 製品の 着色, 着臭, 変味など物理的, 化学的, 味覚的変質に対 する影響を特に考虑しなければならない。

* 第 34 回腐食防食討論会, 大阪 $(1987.10)$ 飞て発表 ** 干006 札幌市西区手稲前田 419 の 2 (419-2, TeineMaeda, Nishi-ku, Sapporo, 006 Japan)

*** $\bar{T} 065$ 札幌市東区苗穂町 2 丁目 3 番地 1 号 (3-1, 2cho-me, Naebo-cho, Higashi-ku, Sapporo, 065 Japan)
醬油, 味噌などの調味料は醸造食品領域の中で伝統的 に大きな地位を占めている。一方，その製造工程を防食 技術的に調査，検討すると，装置材料面で更に攻善を必 要とする点が数多く残されているが，これまでこの分野 飞関する系統的な研究は極めて少ない。装置材料として

\footnotetext{
**** $\bar{T} 229$ 相模原市大山町 1 番 30 号 (1-30, Oyamacho, Sagamihara, 229 Japan)

***** $\bar{\top} 210$ 川崎市川崎区鈴木町 1 番 1 号 (1-1, Suzuki-cho, Kawasaki-ku, Kawasaki, 210 Japan)

****** $\overline{0} 060$ 札幌市北区北 13 条西 8 丁目 (Kita-13 Nishi-8, Kita-ku, Sapporo, 060 Japan)
} 


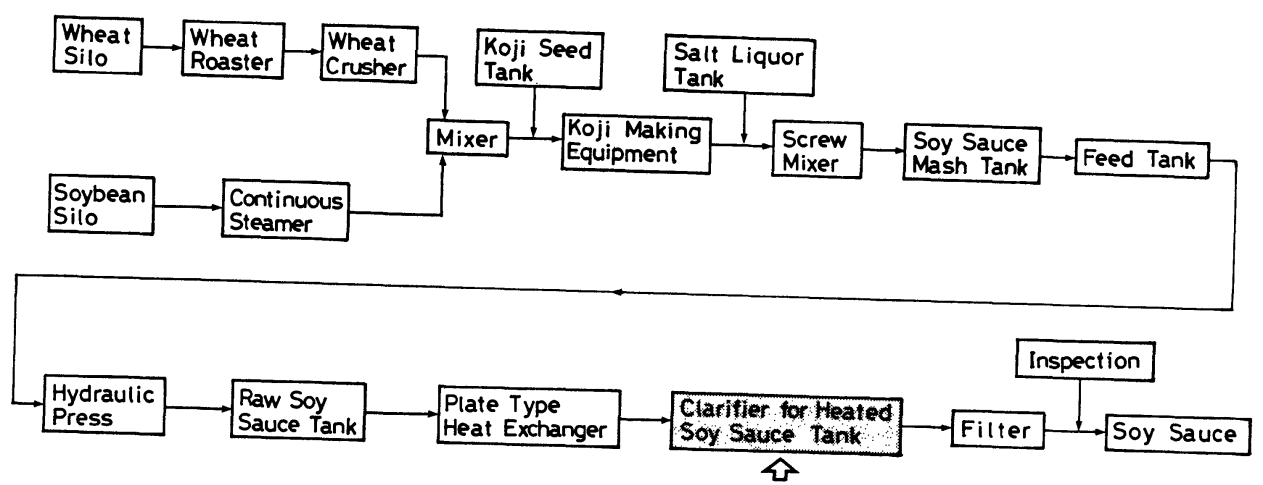

Fig. 1 Block flow diagram of soy sauce brewing process.

のステンレス鋼はそのすぐれた耐食性と衛生性から，食 品製造装置材料用としてきわめて適して和り広い分野で 多用されている。しかし, 醬油等の醸造工程は高濃度の 塩分を含んでいて，ステンレス鋼に対し，孔食，すきま 腐食などの局部腐食を生じさせやすい。

本報は, 醬油醸造の全工程に対し, 最も適正な装置材 料を選定する試みの一環として，醬油火入れ以降の工程 に和けるステンレス鋼の実用性を検討するため, 各種ス テンレス鋼について 10 年間の実地耐食試験を実施し, さらに, 実験室に打ける電気化学的各種腐食試験を併せ て実施して，これらの耐局部腐食性を検証したものであ る。

\section{2. 実験方法}

\section{1 実地耐食試験}

(1) 試験片およびスプールホルダ

試験に供した冷間圧延ステンレス鋼の化学組成を $\mathrm{Ta}$ ble 1 に示す。スプールテスト用の試験片は厚さ $2 \mathrm{~mm}$, 外径 $50 \mathrm{~mm}$, 内径 $7.5 \mathrm{~mm}$ とし, 耐水研磨布 \#400 にて 湿式研磨した。各試験片は離脱や接触を避けるため, ス テンレス鋼製の強固なスプールホルダに組み込み，ま た，ガルバニック腐食を防止するため，試験片相互間お よび試験片と保持具間をテフロンで完全に絶縁した。試 験片数は, オーステナイト系は各 2 枚, フェライト系括 よびオーステナイト・フェライト 2 相系はそれぞれ 1 枚 宛供試した。

(2) 試験環境および試験期間

醬油酸造フローダイヤグラムを Fig. 1 に示す。困中, 矢印で示した火入れ後の清澄タンク (容量 $14 \mathrm{kl}$ ) 内の本 醸造上級和よび本醸造特級醬油環境中に, 各試験片を組 み込んだスプールホルダをそれぞれ固定浸漬し試験を実 施した。試験条件を Table 2 に示す。各試験片は垂直に なるように設置し，1 バッチ約 10 日間の自然冷却中, スプールホルダは常時液中に浸漬されている状態にあ
Table 1 Chemical compositions of stainless steels.

(wt. \%)

\begin{tabular}{|l|c|c|c|c|c|c|c|c|c|c|}
\hline & $\mathrm{C}$ & $\mathrm{Si}$ & $\mathrm{Mn}$ & $\mathrm{P}$ & $\mathrm{S}$ & $\mathrm{Ni}$ & $\mathrm{Cr}$ & Mo & $\mathrm{N}$ & 0 thers \\
\hline SUS 304 & 0.07 & 0.73 & 1.12 & 0.033 & 0.010 & 8.46 & 18.79 & 0.50 & - & - \\
\hline SUS 316L & 0.02 & 0.66 & 1.69 & 0.022 & 0.006 & 12.62 & 16.92 & 2.39 & - & - \\
\hline SUS 317J1 & 0.04 & 0.92 & 1.48 & 0.022 & 0.005 & 15.56 & 18.46 & 4.72 & - & - \\
\hline SUS 444-1 & 0.014 & 0.60 & 0.18 & 0.027 & 0.016 & - & 18.03 & 2.18 & 0.015 & Ti 0.41 \\
\hline SUS 444-2 & 0.010 & 0.54 & 0.25 & 0.030 & 0.013 & - & 18.02 & 1.85 & 0.019 & Nb 0.43 \\
\hline SUS 329J1 & 0.015 & 0.27 & 0.17 & 0.023 & 0.016 & 4.35 & 24.56 & 1.73 & 0.13 & - \\
\hline
\end{tabular}

Table 2 Environmental condition of soaking test in clarifier for heated soy sauce.

\begin{tabular}{|c|c|c|}
\hline \multirow[b]{2}{*}{ Component } & Brewed & Sauce \\
\hline & High Grade & Special Grade \\
\hline $\mathrm{NaCl}$ & 17.2 & 16.8 \\
\hline Total Nitrogen (g/dl) & 1.38 & 1.55 \\
\hline$\left(15^{\circ} \mathrm{C}\right)$ & 22.0 & 22.4 \\
\hline $\mathrm{pH}$ & 4.7 & 4.7 \\
\hline Direct Reducing Sugar $(\mathrm{g} / \mathrm{dl})$ & 2.8 & 3.8 \\
\hline Acidity I (ml) & 12.2 & 12.9 \\
\hline Titratable Acidity (ml) & 21.1 & 23.1 \\
\hline Right Extract (g/dl) & 17.8 & 20.0 \\
\hline Maximum Temp. $\quad\left({ }^{\circ} \mathrm{C}\right)$ & 70 & 85 \\
\hline
\end{tabular}

る。清澄タンク内に拈ける 1 バッチごとの温度変化を Fig. 2 に示す。試験期間は, オーステナイト系は 1976 年 11 月から 1986 年 7 月の間, フェライト系和よびオ ーステナイト・フェライト 2 相系は, 1983 年 11 月から 1986 年 7 月の間とした。

(3) 腐食状況の観察

試験片の腐食状況を定期的に検査するため, 毎年 1 回 スプールホルダを解体し, 水洗, 乾燥後重量測定を実施 した。さらに，腐食の状況を肉眼観察によるスケッチお よび写真撮影により記録し，腐食進行の度合を把握し た。孔食は, 発生したピット数および光学顕微鏡によっ て測定した最大ピット深さによって評価した。すきま腐 


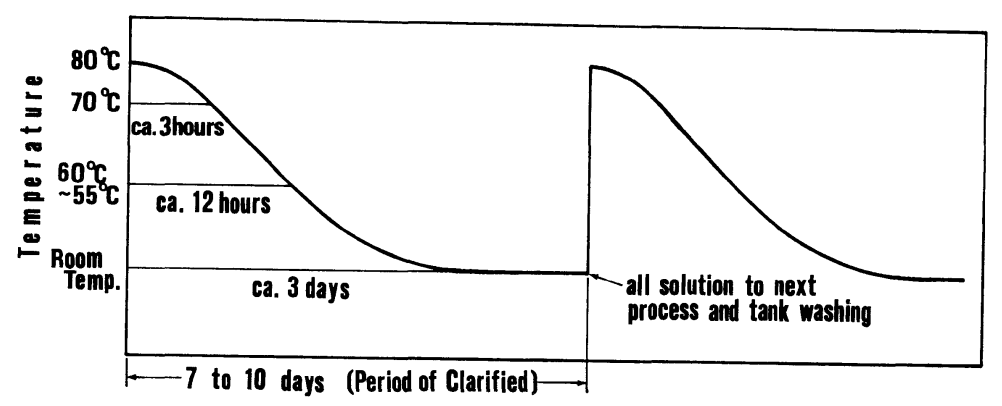

Fig. 2 Schematic diagram of temperature change in clarifier for heated soy sauce. Cooling method: Natural Cooling Cycle: Thirty cycles per year

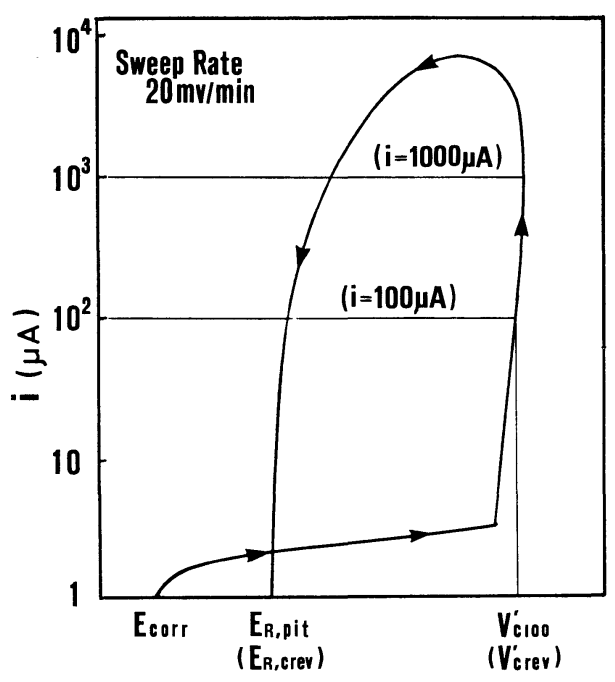

Fig. 3 Schematic cyclic polarization curve.

食については，テフロンスペーサと接触する試験片中心 部の直径 $12 \mathrm{~mm}$ 以内の表面をすき形成領域と定め, その箇所に発生したすきま腐食の総面積を測定しすすき ま形成領域との割合を算出してこれをすきま腐食率 $(\%)$ とした。

\section{2 アノード分極特性測定 ${ }^{1) ~ 5)}$}

(1) 試料電極拉よび試験環境

Table 1 亿示す冷間圧延板を $20 \mathrm{~mm} \times 30 \mathrm{~mm}$ に加工 後, 圧延面の一面を \#600 の研磨布で研磨し，30\% 硝酸 水溶液で不動態化処理を施し、リード線をはんだ付けし た後, 研磨面を残して全面をシリコンシーラントで被覆 乙試料電極とした。不動態化処理された研磨面は，供試 直前に \#0/3 の研磨布で軽く研磨した。すきま付き電極 については, 極をデルリン製治具にセットし， $1 \mathrm{~mm} \times 10$ $\mathrm{mm} \times 20 \mathrm{~mm}$ のテフロンシートをすきま材にして締め付
けた。試験溶液は, Table 2 に示した本醸造上級, 本醸 造特級醬油拉よび $17.2 \%$ 食塩水溶液を用い, 試験温度 は $70^{\circ} \mathrm{C}$ とした。

(2) アノード分極曲線測定

醬油あるいは $17.2 \%$ 食塩水溶液 $250 \mathrm{ml}$ を電解セルに 注ぎ，恒温水槽中で試験温度に保持した。溶液雾囲気は 非脱気状態とした。試料電極を供試液中に浸漬し, 浸漬 直後抢よび $5 \mathrm{~min}$ 経過後の自然電極電位 $E_{\mathrm{corr}} 5^{\prime}$ を測定 後, 電位掃引速度 $20 \mathrm{mV} / \mathrm{min}$ の動電位法でアノード分 極させた。アノード分極曲線の模式図を Fig. 3 亿示す。 孔食特性電位は自由面電極を用い, 外部アノード電流が $100 \mu \mathrm{A} / \mathrm{cm}^{2}$ となる電位を孔食電位 $V_{\mathrm{O}^{\prime}}{ }^{\prime} 100$ とし, さらに アノード分極を行い, 外部電流が $1000 \mu \mathrm{A} / \mathrm{cm}^{2}$ に達し た点で電位を逆掃引して孔食停止電位 $E_{\mathrm{R}, \mathrm{pit}}$ を求め た。すきま腐食特性電位 $\left(V^{\prime}{ }_{\text {crev }}\right.$ お。よび $E_{\mathrm{R}}$, crev $)$ につい ては，すき付き電極を用い， $V_{\mathrm{C}}{ }^{\prime} 100$ ならびに $E_{\mathrm{R}, \mathrm{pit}}$ の 測定と同様の操作によって求めた。電位の照合は SCE によった。

\section{3 試験環境溶液中の溶存酸素濃度測定}

醬油, グルタミン酸, ブドウ糖㐨よび食塩水溶液中の 溶存酸素濃度について, 次のような方法によりその時間 的変化を測定した。

試料液は，本醸造特級醬油，1\% グルタミン酸， $1 \%$ ブドウ糖㧍よび $17.2 \%$ 食塩水溶液を用い, あらかじめ それぞれ $85^{\circ} \mathrm{C}, 15$ 分間加熱し殺菌した。 $200 \mathrm{~m} l$ メスシ リンダに試料液を $150 \mathrm{~m} l$ とり, 閉栓後手動にて 15 分 間激しく振とうし空気飽和の状態とした。空気飽和の試 料液を溶存酸素測定用 $140 \mathrm{~m} l$ ビーカに移し, 液をオー バーフローさせて密栓し残留空気層を無くした。マグネ チックスターラにて試料液を攪找しつつ, 溶存酸素濃度 を 24 時間連続計測し XY レコーダにより記録した。 溶存酸素濃度計は, セントラル科学製 UC-11 DIGITAL $\mathrm{DO} / \mathrm{O}_{2} /$ 水温メータによった。 


\section{3. 実地結果および考察}

\section{1 実地耐食試験}

（1）孔食拉よびすきま腐食発生率

10 年間 (一部 3 年間) 実地浸漬試験を行った各試験片 の平面执よび側面のすべてについて, 発生した孔食の経 年別ピット数, 最大ピット深さ特よびすきま腐食率を測

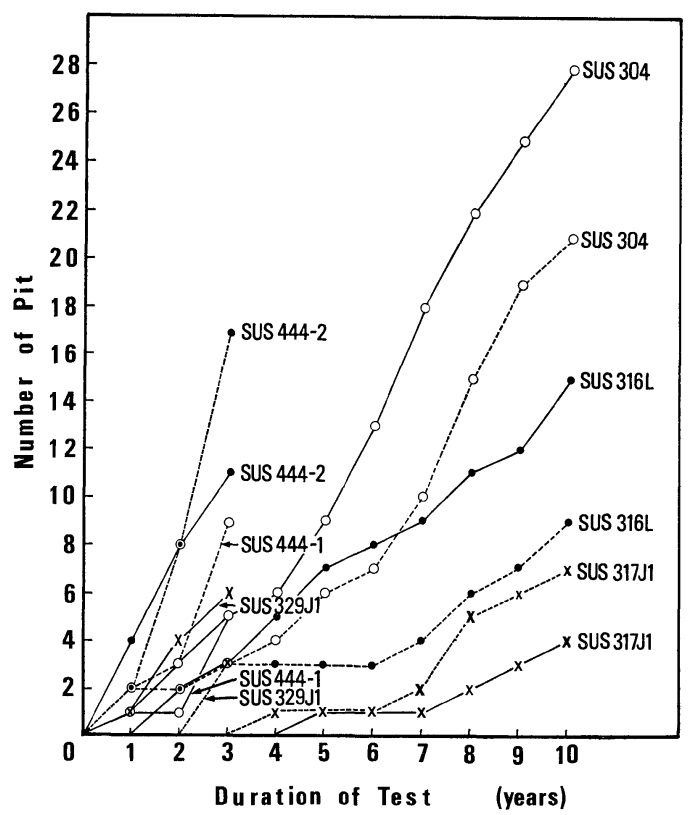

Fig. 4 The transition of pitting growth.
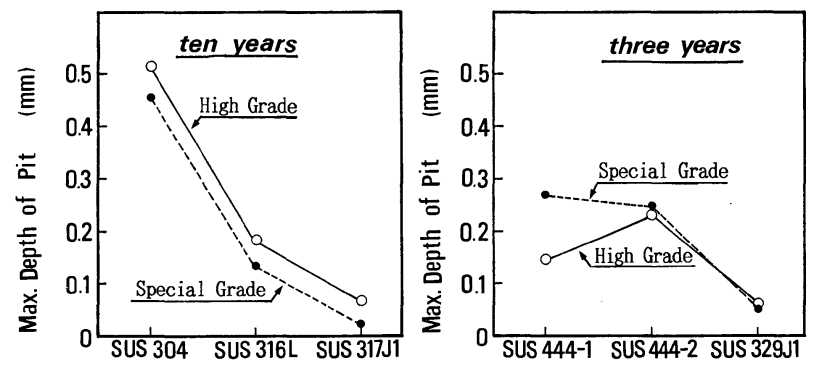

Fig. 5 Maximum depth of pit.
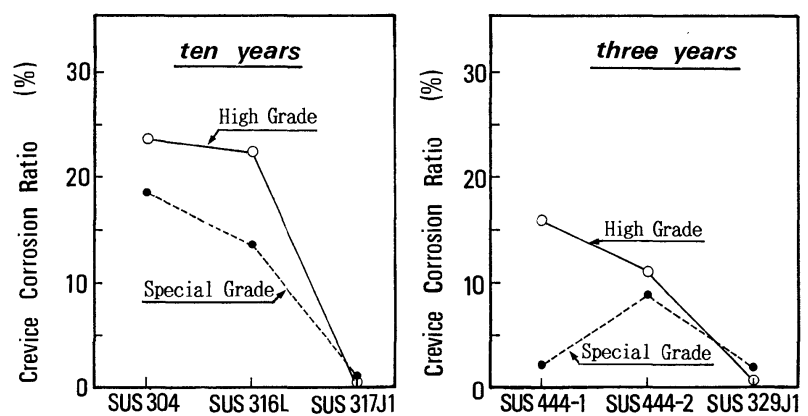

Fig. 6 Crevice corrosion ratio.
定した。この結果から, 鋼種, 環境条件, 試験期間等によ って，孔食あるいはすきま腐食の発生率がぞのように変 化するかを解析した。各鋼種の孔食発生数の推移を Fig. 4 亿示す。最大ピット深さをFig. 5 亿，すきま腐食率を Fig. 6 にそれぞれ示す。これらの図から, 鋼種による局 部腐食発生状況の差が明確にあらわれている。

ピット数, 深さ怙よびすきま腐食発生率ともオーステ ナイト系は SUS 304, 316 L, 317 J 1 の順に低下し, 醬 油の種類別では上級よりも特級の方が腐食性が若干低い ことがわかる。一方，フェライト系拈よび 2 相系では， SUS $329 \mathrm{~J} 1$ の耐食性が安定してすぐれ，SUS 444 は全 般にこれより劣り, 鋼種, 醬油の種別によって不安定に 変動する。

(2) 重量変化

各試験片の経年重量変化は極めてわずかで，材料別， 環境別に腐食の発生度合いの差を解析することは困難で あった。

\section{2 アノード分極特性}

本䁔造上級, 本醸造特級醬油抒よび $17.2 \%$ 食塩水溶 液中に拈沙る各種ステンレス鋼の電気化学特性 $E_{\mathrm{corr}} 5^{\prime}$, $V_{\mathrm{C}}{ }^{\prime}{ }_{100}, E_{\mathrm{R}, \mathrm{pit}}, V^{\prime}{ }_{\text {crev }}$ お拈よ゙ $E_{\mathrm{R}, \text { crev }}$ について, Fig. 7 抒よび Fig. 8 に示す。これらの結果から，3 溶液環境間 には大きな相違は認められず，扮拉む称同様な傾向を示 している。各鋼種ともすきまの存在によって発生電位は $20 \mathrm{mV}$ 程度, 再不動態化電位は $100 \mathrm{mV}$ 程度卑となる。 鋼種別では，444 が安定化元素の種類によらずいずれ 


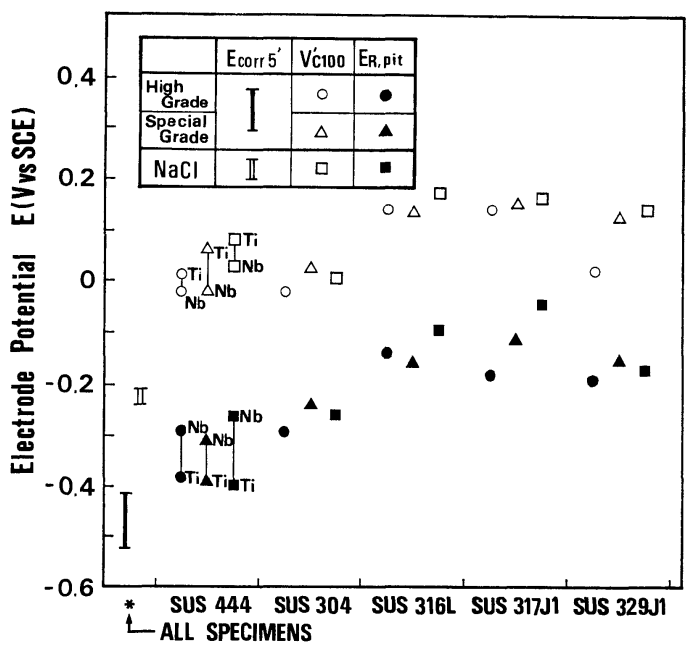

Fig. $7 V_{\mathrm{C} 100}^{\prime}, E_{\mathrm{R}, \mathrm{pit}}$ and $E_{\text {corr }} 5^{\prime}$ in brewed soy sauce and $17.2 \% \mathrm{NaCl}$ solution.

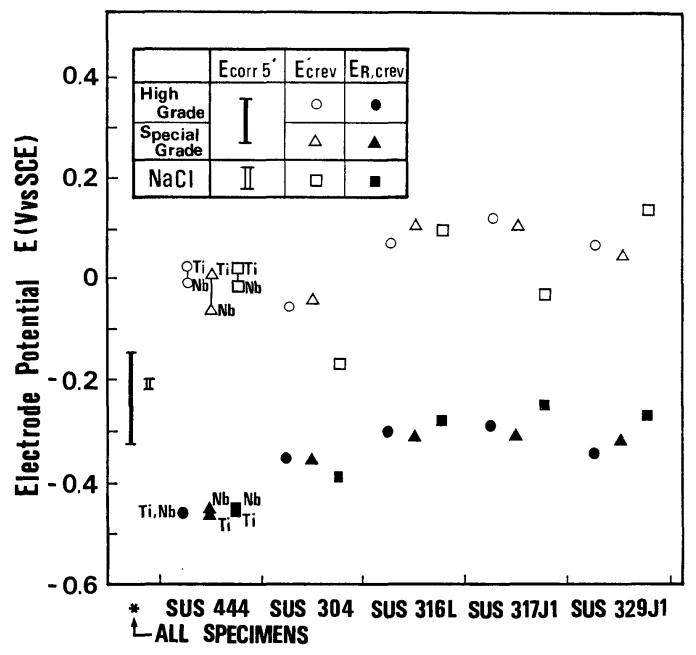

Fig. $8 V_{\text {crev }}^{\prime}, E_{\mathrm{R} \text {, crev }}$ and $E_{\text {corr }} 5^{\prime}$ in brewed soy sauce and $17.2 \% \mathrm{NaCl}$ solution.

の特性電位も最も卑であり, 304 がこれに続き, 次いで $316 \mathrm{~L}, 329 \mathrm{~J} 1$ の順となり，317 J 1 がもっとも貴な電位 を示している。なお，浸漬初期の自然電極電位について は, 醬油の種類および鋼種によらず, 自由面では -0.5 V vs. SCE 程度であったが，すきまの存在によって多少 貴方向に移行し $E_{\mathrm{R}}$ に近つく。しかし, 食塩水の場合は, すきまの有無によらず， $-0.2 \mathrm{~V}$ 程度と著しく貴になる。 このことから, 腐食性が単に塩化物濃度のみによって決 まるものではなく，共存する他の成分によって大きな影 響をらけることを示唆している。

\section{3 試験環境溶液中の溶存酸素濃度}

本醉造特級醬油， $1 \%$ グルタミン酸， $1 \%$ ブドウ糖お

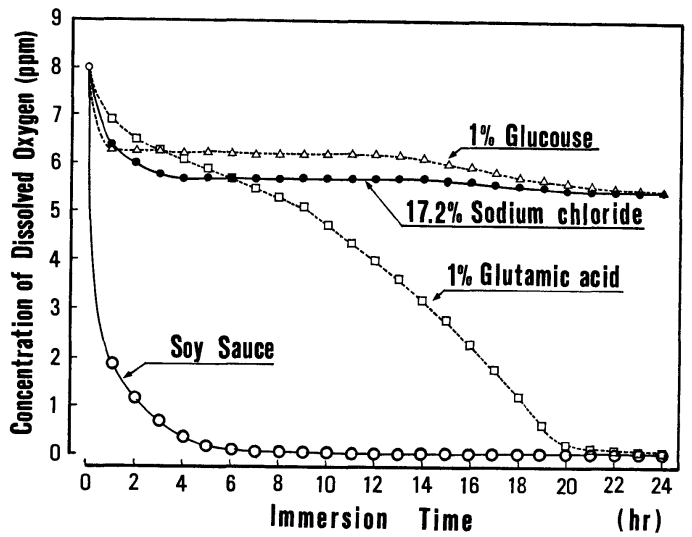

Fig. 9 Variation of dissolved oxygen concentrations with time in naturally brewed special soy sauce, $1 \%$ glutamic acid, $1 \%$ glucouse and $17.2 \% \mathrm{NaCl}$.

よび $17.2 \%$ 食塩水溶液中の溶存酸素濃度の経時的変化 をFig. 9 に示す。これより, 食塩水溶液は測定開始時の $8.0 \mathrm{ppm}$ が 20 時間後も $5.4 \mathrm{ppm}$ を保持しているのに対 し, 醬油の場合は時間経過に伴い溶存酸素濃度が急激に 減少し, 約 7 時間経過以降はほぼ 0 になる。なお, ブ ドウ糖水溶液は食塩水溶液とほぼ同様の傾向を示してお り,グルタミン酸水溶液は約 20 時間経過後ほぼ 0 にな ることがわかる。

醬油環境およびグルタミン酸水溶液中での溶存酸素の 経時的減少の理由に関しては現在検討中であるが，醬油 中の各種アミノ酸による化学的還元反応によるものと推 定される。

\section{4. 結言}

(1) 醬油醸造工程火入れ以降の清澄 タンク内環境に 括いて，10 年間実施したオーステナイト系各種ステン レス鋼の実地耐食試験の結果から，孔食発生度合いは， 304が著しく, $316 \mathrm{~L}$ がこれに次ぎ， $317 \mathrm{~J} 1$ はその程度が 極めて軽いこと, 与きま腐食についても, 孔食の場合と 同一の順序を示していた。

また, 3 年間実施したフェライト系和よびオーステナ イト・フェライト 2 相系ステンレス鋼に関する実地耐 食試験の結果から, $329 \mathrm{~J} 1$ は 444 に比して, 孔食および すき腐食の発生度合いが比較的軽い。

な拉, 本醸造上級と特級の環境間では, 各種ステンレ ス鋼の局部腐食の発生度合いに顕著な差異は認められな w。

（2）長期実地耐食試験の 結果と, アノード 分極特性 の測定結果から得られた知見は，良く対応する。すなわ ら, 醬油のような濃厚な塩化物溶液に対するステンレス 
鋼の耐食性は, 高 Mo のオーステナイト系がすぐれ， Mo 含有量の少ないフェライト系およびオーステナイ ト・フェライト 2 相系の耐食性は相対的に低下すると いえる。

（3）醬油火入れ以降の工程に和いて, 耐食性の点で 推奨できるステンレス鋼鋼種は $317 \mathrm{~J} 1$ であると考える。 なお゙，同環境で同時に耐食試験を行ったチタン (TP 28 C) は完全耐食性を保持している。

（4）醬油执よび食塩水中の溶存酸素濃度測定, さら に，これら環境に和ける自然電極電位測定結果から, 醬 油中のステンレス鋼は, 溶存酸素濃度低下効果により,
局部腐食の発生, 成長が抑制されている可能性が認めら れる。

(Received August 12, 1988)

文献

1）辻川茂男, 久松敬宏：防食技術, 29, 37 (1980).

2）辻川茂男, 張恒, 久松敬宏：防食技術, 32, 97 (1983).

3）辻川茂男, 張恒, 久松敬宏：防食技術, 32, 149 (1983).

4）岡山伸，上杉康治，辻川茂男：防食技術， 36, 157 (1987).

5）日本工業規格, JIS G 0577-1981. 